\title{
Preparation for Academic Librarianship: A Survey
}

\section{Gemma DeVinney and Patricia Tegler}

Library school, the library as hiring institution, and the librarian, all contribute, in varying degrees, toward the education of the entry-level academic librarian. The relative contribution of each group is frequently disputed and worthy of empirical analysis. Past efforts have presented views on how the librarian should be educated. The authors characterize perceptions of entrylevel State University of New York librarians regarding the primary means by which they believe they should be educated for specific professional activities.

$t$ is commonly agreed that the responsibility for educating entry-level academic librarians is shared by three groups: library schools, hiring institutions, and the librarians themselves. Despite general consensus that each of these groups share responsibility for the educational process, the specific nature of their respective roles is vigorously debated.

The library education debate in both the literature and at professional meetings has focused on the following questions: Should the curricula of library schools emphasize theory or practice, or, should both be given equal attention? Should library schools focus on preparing students for employment in specialized positions and environments, such as academic libraries, or might a general core program provide the basic preparation for library work?

The roles of the hiring institution and the beginning librarian are similarly open to question. Should the employing library be expected to provide extensive on-thejob training, or simply orientation to its particular policies and procedures? And, how far does the responsibility of the beginning librarian extend? Should a beginning librarian identify the gaps in personal professional knowledge and assume the responsibility for filling those gaps through informal self-instruction or formal continuing education programs?
Discussion of these questions has generally focused on how librarians should be educated, rather than how they are educated, and has rarely reflected the perceptions of entry-level librarians who have recently begun to use their education. Accordingly, we decided to ask a number of beginning academic librarians about their actual job responsibilities, and the manner in which they learned to perform their duties. Finally, we sought to elicit their opinions about how their job responsibilities should have been taught. Librarians employed by the State University of New York were selected for our study.

\section{METHODOLOGY}

In the fall of 1980 we sent introductory letters to the library directors of the four SUNY (State University of New York) university centers and the twelve SUNY fouryear colleges of arts and science (excluding Empire State College which has no campus per se). The letters asked for the director's cooperation in distributing the questionnaires to librarians on their staffs who had received graduate degrees in 1976 or later. Three university center library directors and ten four-year college library directors cooperated. Questionnaires were distributed to sixty-seven academic librarians who met our criterion.

The questionnaire was divided into four

Gemma DeVinney is former senior assistant librarian, University Libraries, State University of New York at Buffalo, and current doctoral candidate, School of Information and Library Studies, State University of New York, Buffalo. Patricia Tegler is assistant reference librarian, University of Illinois at Chicago. 
parts. Part I solicited background data such as position title, year of library degree, rank, other graduate degrees, and whether the librarian was considered primarily a public service or technical service librarian.

Part II presented a checklist of twentyseven professional activities typical of academic librarians. The checklist was developed by studying advertisements for entry-level academic library positions, and by consulting both public and technical service colleagues. Space was provided at the end of the checklist for noting additional major professional activities.

The librarians were asked in Part III to indicate which of four methods, library school education, on-the-job training, self-instruction, or continuing education, was the most important preparation for their job responsibilities. ${ }^{*}$ The first three methods of preparation directly correspond to the three groups with the responsibility for educating library professionals as discussed above. The fourth, continuing education, requires the participation of the individual as well as that of some institution. The institution can be a library school, library, professional organization, or some other group willing to plan and develop a continuing education program.

In Part IV the respondents were given an opportunity to indicate which of the four categories, in their opinion, should assume primary importance for job preparation. It was not possible in either Part III or Part IV to indicate that two methods were, or should be, equally involved in professional preparation.

\section{RESULTS AND DISCUSSION}

Fifty-seven questionnaires were com- pleted and returned to us, a response rate of 85 percent. Of these, fifty-four were analyzed.t Forty-five of the respondents were classified as assistant librarians, eight as senior assistant librarians, and one was a technical assistant. $\ddagger$ The group was fairly evenly divided according to the date of receipt of the MLS degree. Ten received their MLS degrees in 1976, thirteen in 1977, twelve in 1978, twelve in 1979, and seven in 1980 . Thirty-three of the respondents considered themselves primarily public service librarians. Eighteen indicated that they were technical service librarians. Two were involved in both areas, and one individual did not respond to the question.

\section{Activity Analysis}

Table 1 lists in descending order of frequency the types of activities that beginning librarians in the SUNY system perform. The jobs of these librarians appear to be extremely diverse. On the average, each librarian performed 15 different activities either regularly or occasionally. The duties of public service and technical service librarians appear to be equally varied. Public service librarians averaged 16 activities, while technical service librarians were involved in 14.5 . The lowest number of duties was 5 , indicated by one respondent, and the highest was 23 , also noted by one respondent. Fifteen librarians listed duties other than the 27 provided on the questionnaire. Additional duties included the following: (1) processing of special materials (five respondents); (2) preparing exhibits (three respondents); (3) card catalog maintenance (four respondents); and (4) work with audiovisual equipment and materials (two respondents).

*These methods were defined as follows: 1) library school education (e.g., coursework, practica for credit); 2) formal on-the-job training initiated by the employer (e.g., in-service group training sessions, individual training session with a supervisor); 3 ) self-instruction (e.g., informally consulting with colleagues, reading, "learning by doing"'); 4) continuing education sponsored by groups other than the employing library (e.g., seminars, conferences, courses).

tThree questionnaires were not completely filled out and could not be analyzed.

fLibrarians in the SUNY system typically hold one of four ranks: assistant librarian, senior assistant librarian, associate librarian, and librarian. Occasionally individuals with MLS degrees are classified as technical assistants. Technical Assistants do not hold faculty rank. 
TABLE 1

LIBRARIAN ACTIVITIES

Activity

Answering reference questions

Discussing library policies \& procedures with patrons

Supervising personnel

Preparing reports and memoranda

Selecting library materials (print \& nonprint)

Library instruction lectures

Verifying bibliographic data

Participating in library committee work

Training personnel

Formulating policies/procedures

Participating in faculty liaison activities

Evaluating personnel

Developing user guides in print format

Hiring personnel

Participating in university committee work

Deciding on the acceptability of gift materials

Participating in national/state/regional committee work

Writing for publication

Copy Cataloging

Original cataloging of other formats

Preparing \& monitoring budgets

Original cataloging of monographs

Selecting \& working with vendors

Online bibliographic searching

Teaching credit-bearing library instruction courses

Original cataloging of serials

Developing user guides in nonprint format

By analyzing the jobs done by beginning librarians, we found a number of surprises. Ninety-four percent of all librarians, both technical and public service, were involved in answering reference questions. Only three respondents, all technical service librarians, indicated that they were never involved in reference activities. Edwards, in his study of California beginning academic librarians, also found that a high percentage of the librarians were involved with reference activities. ${ }^{1}$ In total, fifteen technical service librarians out of the eighteen who responded indicated involvement in answering reference questions. Another public service function, "discussing library policies and procedures with patrons," was the second most frequently engaged in activity. Forty-nine, or 91 percent of our respondents, were involved in this function. Many of the libraries we surveyed employ relatively few professionals, therefore, each librarian has the op- portunity to work in a variety of job capacities.

Another interesting finding was that 87 percent of the respondents indicated they supervised personnel on a regular or occasional basis. This corresponds with Edwards' findings. ${ }^{2}$ An analysis of the inhouse job titles given respondents revealed that fewer than five were administrative positions. Most of the librarians' titles were reference librarian, cataloger, or media librarian. Yet, all but seven indicated that they performed supervisory functions. It is probable that in many cases the beginning librarians are supervising nonprofessional personnel, that is clerks, technical assistants, and students. Still, the large number of entry level librarians engaged in supervision is noteworthy.

The existence of faculty status for librarians in SUNY schools, with resulting emphasis on professional contributions, and university and community service, may account for the large numbers of beginning librarians who are involved in committee work and writing for publication. Not surprisingly, 81 percent of the librarians surveyed indicated that they were involved with library committees. Fifty-two percent were members of university-wide committees, indicating early career involvement in university governance. Surprisingly, 46 percent participated in committee activities at regional, state, and/or national levels. The emphasis placed on committee work varies considerably from campus to campus.

Other duties performed by more than one-half of the librarians are: preparation of reports and memoranda ( 85 percent); selection of print and nonprint library materials (83 percent); verification of bibliographic data (81 percent); formulation of procedures and policies (76 percent); participation in faculty liaison activities (72 percent); and development of user guides in print format (63 percent).

\section{Actual Method \\ of Preparation for \\ Job Responsibilities}

As mentioned earlier, Part III of our questionnaire allowed respondents to in- 
dicate which method was most used for job preparation.

Only five librarians agreed on where they had learned specific job techniques. There was general agreement, however, that serials cataloging and copy cataloging were learned on-the-job. Self-instruction was listed as the primary method of learning for those involved with writing for publication and those serving on university, regional, state, or national library committees. Beyond these, there was little consensus. The one job most of the librarians were involved with, answering reference questions, was the one with which there was least agreement. Thirty-three percent of those involved with reference believed that library school had been most important in preparing them for their reference responsibilities. Thirty-six percent felt that on-the-job-training was most important, while 31 percent felt that they had learned about reference through selfinstruction.

None of the respondents considered library school as a primary means of preparing them for professional activities, including committee work and writing for publication, bibliographic instruction activities, hiring and training personnel, or serials cataloging. A small percentage of the librarians indicated that library school had prepared them for evaluating and supervising personnel, original cataloging of special formats, copy cataloging, explaining policies and procedures, and acting as liaison with faculty.

Continuing education was thought to be an important method of learning by even fewer of the respondents. In only nine categories was it noted at all, and in only two categories, teaching library instruction courses and writing for publication, did over 10 percent consider it the primary learning method.

Largely, the respondents considered on-the-job-training as their most important means of learning job responsibilities. At least 50 percent of the librarians indicated that they had learned the following activities primarily on-the-job: discussing library policies and procedures with patrons, online bibliographic searching, giving library instruction lectures, doing original and copy cataloging of all formats, and evaluating personnel. The exceptions to on-the-job-training were: developing user guides, serving on university, state, national, or regional committees, writing for publication, and selecting library materials.

Self-instruction was also considered an important means of learning professional duties. Jobs emphasizing personal skills such as committee work, writing, and faculty liaison were thought to have been learned primarily through selfinstruction. The exceptions to selfinstruction learning were: original cataloging of serials and monographs, copy cataloging, online searching, and verification of bibliographic data.

In summary, the results of Part III of the questionnaire indicated that respondents felt self-instruction and on-the-jobtraining were the most important means of learning specific job responsibilities. Library school was, in their estimation, of substantially less importance, as was continuing education.

\section{Preferred Method of Preparation for Job Responsibilities}

In Part IV of the questionnaire, respondents were asked to indicate which of the four educational methods should be of primary importance. Expectations for library school appear to be relatively high. More than 75 percent of those librarians performing online searching and original cataloging of monographs believed that these jobs should be learned in library school. Over 50 percent of the librarians performing these duties thought that the following activities should be learned through the formal library education system: answering reference questions, developing user guides, verifying bibliographic data, selecting library materials, cataloging serials and other formats, and preparing budgets.

On-the-job-training was listed as the primary method of preparing beginning librarians for explaining library policies, teaching library instruction courses, selecting gift materials, working with vendors, serving as faculty liaison, copy cataloging, traïning, supervising and evaluating personnel, and formulating policies. The percentage of respondents 
selecting on-the-job-training as the preferred method of learning was low for only one activity, that of writing for publication.

Unlike library school and on-the-jobtraining, self-instruction was seldom the preferred primary method of learning. In only five categories did more than 25 percent of the librarians indicate that they believed self-instruction should be the major means of preparation for professional responsibilities. These activities: serving on committees, preparing reports, and writing for publication, all emphasize communication skills. There were several activities which none of the respondents believed should be learned through selfeducation. These were: online bibliographic searching, working with vendors, original cataloging of monographs and serials, and copy cataloging. In general, relatively few of the librarians thought that self-instruction should be the primary means of learning job responsibilities.

Continuing education was not considered as a primary method of preparing for professional duties. We interpret this, not as a lack of interest in continuing education, but rather, as a belief that continuing education is most effective when it supports previous learning.

Although there is no clear consensus, there is a strong indication that, as a group, the respondents thought that library schools and hiring institutions should share the responsibility for preparing beginning librarians for their jobs. In some areas, particularly those emphasizing communication skills, the librarians were willing to assume responsibility for their own development.

\section{CONCLUSIONS}

The results of our survey suggest to us that there is little agreement among beginning librarians in the SUNY system regarding the primary method by which they learned to do their jobs. It is apparent, however, that despite disagreement about particular activities, there is general agreement that self-instruction and onthe-job-training were of greater importance in preparing beginning librarians for their current positions than was library school.

When reviewing the librarians' perceptions about actual versus ideal preparation, it is interesting to note the relationships between self-instruction, library school, and on-the-job-training. It appears that the respondents believe that they assumed responsibility for learning the jobs which were not adequately taught by their library schools or hiring institutions. It also appears that they do not believe this is how it should be.

Although there is no clear consensus regarding the primary responsibility for the education and training of librarians, some conclusions can be drawn. Survey respondents indicated that responsibility for professional education should be shared by library schools and the hiring institutions. Duties that are largely institution-specific, or less likely to be theoretically based, such as gift and vendor selection, or the explanation of policies, should be handled primarily through on-the-job-training. Job functions that are common to all libraries should be learned primarily through library school: reference, online searching, bibliographic verification, selection of library materials, and cataloging. Librarians willing to assume primary responsibility for their learning are those involved with personal professional development, such as serving on committees and writing for publication.

There are several unresolved questions. Are the perceptions of these librarians representative of all beginning academic librarians? Do their ideas about library education match those of library educators and administrators? If not, do these differences in expectations explain some of the continuing dissatisfaction with the library education system? The answers to these questions await further research.

\section{REFERENCES}

1. Ralph M. Edwards, The Role of the Beginning Librarian in University Libraries, ACRL Publications in Librarianship, no.37 (Chicago: American Library Association, 1975), p. 38.

2. Ibid., p. 42. 